International Journal of Physical Sciences and Engineering
Available online at http://sciencescholar.us/journal/index.php/ijpse
Vol. 2 No. 2, August 2018, pages: $11 \sim 20$
e-ISSN : 2550-6943, p-ISSN : 2550-6951
http://dx.doi.org/10.29332/ijpse.v2n2.133

\title{
Drills Forehand Training Strategy on the Stroke of Forehand Drive Ability in Tennis
}

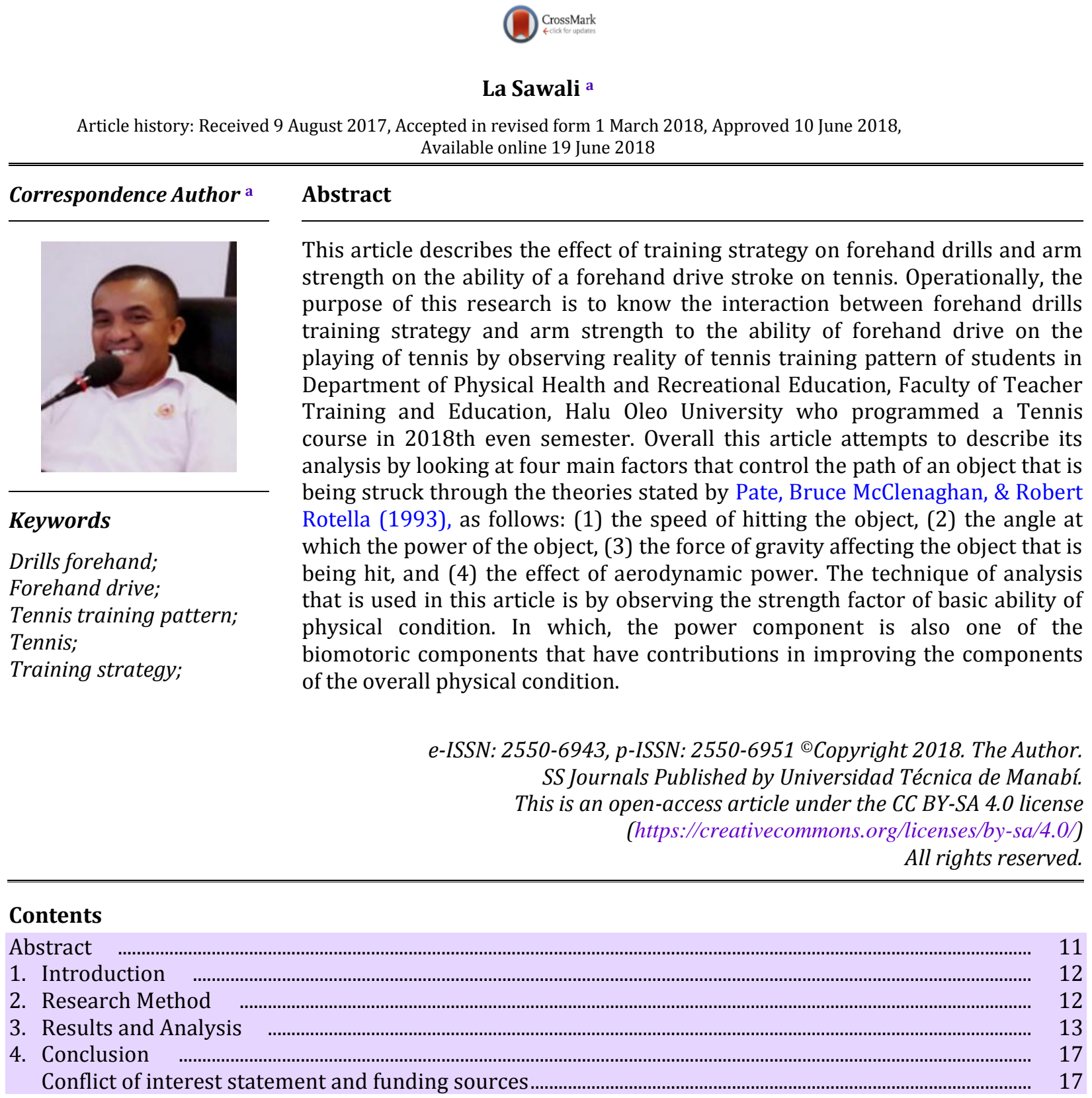

a Physical Education Dept. of Education Faculty of Halu Oleo University, Kendari, Southeast Sulawesi, Indonesia 93232 


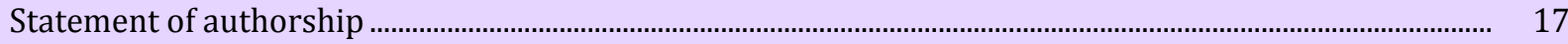

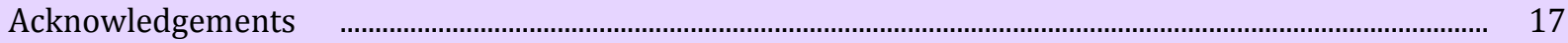

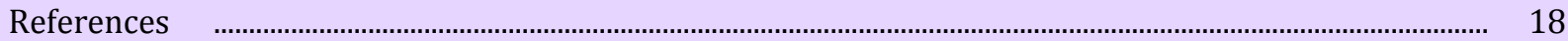

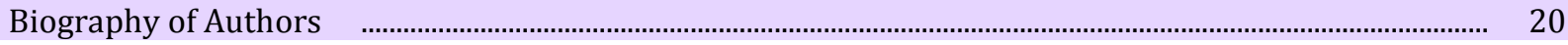

\section{Introduction}

Exercising is one of the efforts to establish a reliable development Indonesian people character. Wherein, the exercising well will be able to improve their physical and mental ability to ultimately encourage the performance of personality to be able to perform work tasks appropriate profession well. According to Siahaan (2017), at this time the sport is not developing for achievement only. There are many benefits that can be obtained by sports doers. Siahaan further argued that exercise also affects to physical and psychological health, including: (1) reducing stress, (2) improving brain performance, (3) reducing anxiety and depression, (4) facilitating brain neurotransmitters, (5) as anti aging, (6) enhancing happiness and confidence.

One of the sports is often done by people in effort to improve physical freshness is playing tennis. The tennis can be done by children or adults and male or female. In this case, this evidenced by the formation of clubs in the area as well as in urban areas and the increasing number of tennis as well as the increasing number of enthusiasts of the tennis games.

Tennis is one of the sports with own characteristic and basic drive, so it requires special coaching to create the coordination of movement in order to achieve maximum progress by following the right drive and movement. Lardner (1994: 56) said that tennis is one of game which is categorized in small ball games and it is very popular. In addition, tennis has improved function in the physical fitness for the perpetrators as well as a medium to take great relationships between players to achieve best prestige. Tennis is played on a closed or open court with predefined measures using rackets and balls (Lardner, 1994: 89). In principle, the tennis game is done by hitting the ball with a racket that passes over the net and into the opponent's court part.

In tennis to achieve an optimal performance a player needs four preparation in major aspects: (1) physical condition; (2) mental readiness; (3) technical preparation; (4) and play strategies. In addition to these four things, the system of coaching factors, facilities and infrastructure as well as also supporting environments affect to develop of athlete's achievement in this sport. Thus, these things required special attention in preparation and coaching.

A tennis sport as any other sports are required intensive and focus training. Many training strategies are applied by the trainer for stimulate of technique development. The forehand drive is one of the most commonly used struck techniques in tennis, both on training and matches. However, in most cases the trainer is put the development of forehand drive training just for service exercise to across the ball at the opponent's area only. Some trainers do not attempt to direct this exercise to train its strength and accuracy.

Forehand drive is divided into two types, namely forehand flat and forehand topspin lobs. The forehand flat is a pitch in tennis that starts from the racket swing backwards at the position between waist and shoulder with a ball in high speed, a flat ball direction, and a slight spin. Whereas, forehand topspin is a lob, that is carried out until the ball stroke forward in high speed (turning very high speed). When a player is doing stroke by forehand topspin the rotates of ball direction forward and swoop down, the air resistance is greater in the upper center of the ball (see Magheti, 1990).

\section{Research Method}

\section{Methods and Materials}

This article describes the effect of training strategy on forehand drills and arm strength on the ability of a forehand drive stroke on tennis. Operationally, the purpose of this research is to know the interaction between forehand drills training strategy and arm strength to the ability of forehand drive on the playing of tennis by observing reality of tennis training pattern of students in Department of Physical Health and Recreational Education, Faculty of Teacher Training and Education, Halu Oleo University who programmed a Tennis course in 2018th even semester. 
Overall this article attempts to describe its analysis by looking at four main factors that control the path of an object that is being struck through the theories stated by Pate, Bruce McClenaghan, \& Robert Rotella (1993), as follows: (1) the speed of hitting the object, (2) the angle at which the power of the object, (3) the force of gravity affecting the object that is being hit, and (4) the effect of aerodynamic power. The technique of analysis that is used in this article is by observing the strength factor of basic ability of physical condition. In which, the power component is also one of the biomotoric components that have contributions in improving the components of the overall physical condition.

\section{Results and Analysis}

\section{Finding and Discussion}

The tennis is one of the sports that biomechanically the whole body has its roles at play. One type of stroke involving the arm id called forehand drive. At the moment of doing a forehand drive the player must maximally exert energy to be able to lob the ball and make the ball speed faster and sharper, so that the opponent can't return it well.

Forehand drive stroke uses arms with sequences of motion that is started from a ready position, backswing, impact the ball with the racket, continued movement accompanied by weight movement from the hind legs to the front legs. To gain maximum strength when hitting with a forehand drive, the racket swings backward and the ball timings to be hit must actually be in a regular series of movements.

From a ready position, the weight is on both legs with a slight knee bent, allowing a player to move towards the ball that is ready to be struck. Simultaneously, the arm that holds the racket in ready to wait for the position, it should be relaxed and after the impact of the grip strength and swing backward should be maximized.

There are four main factors that control the path of a struck object as follows: (1) the speed of stroking the object, (2) the angle at which the struck power of the object, (3) the gravitational force affecting the object that is being hit, and (4) the effect of aerodynamics power (Pate, Bruce McClenaghan, \& Robert Patella, 1993: 185). As a player hits a ball which coming from an opponent, the player must uses maximum strength to produce a fast, sharp and directional ball. A tennis player is doing a forehand drive should try to be right in order position to struck it properly, thus improving efficiency and better skills.

This should be adjusted also with the point of weight so that when hitting the ball, can easily be directed to the desired court so that it is difficult to reach by the opponent. The position of a person's weight point varies depending on the position of the body itself. This means that when a person is standing perpendicular, the position of his weight is on the pubic bone, the weight point in affordable position is in the midst of the spine. Similarly, a person who is moving, the position of the weight of the body changed according to the type of movement and body position when moving.

Yudoprasetio (1999: 17), said that the strokes in tennis are classified into three types of strokes: i.e. groundstroke, volleys and overhead stroke. "As for groundstroke punches can be differentiated into several types: a). forehand drive, b). drop shot, c). backhand drive, d). half volley. Meanwhile, Mottram (1996) argued that in tennis there are four basic types of strokes that must be controlled by a field tennis player, such as service, forehand drive (groundstroke), backhand drive (groundstroke) and volley.

One of the drive strokes that need mastering by a tennis player is the forehand drive. Mottram says that a forehand drive stroke is usually expressed as the most easily learned stroke by the first player in playing tennis. This is because beginners relatively do feel easy to return the ball with forehand patterns because the racket is free from the body (ibid, 104).

Brown (1996:24) states that groundstroke forehand leads to the side of body who that holds the racket. The forehand drive stroke is a straight stroke performed from the right side for the right-hand holder and on the contrary for the left-hand holder.

Similar opinion described by Loman (1993: 69), that the forehand drive stroke is done by using the front of the hand and facing forward because it is called a forehand drive stroke. To get used to the forehand stroke, the grip should form a right angle. Launch the right hand to the end of the racket handle. Hold the racket as if you were shaking hands with friends. Move your fingers until the handle feels good (compared Yajuvendra Singh, Rajpoot, Ghai.G.D. \& Bagchi Amritashis 2015: 7).

Sawali, L. (2018). Drills forehand training strategy on the stroke of forehand drive ability in tennis. International Journal Of Physical Sciences And Engineering (IJPSE), 2(2), 11-20. doi:10.29332/ijpse.v2n2.133 
Besides some of the opinions mentioned, Gautschi (1997: 98) also said that the body demeanors while doing a forehand drive is to be held the neck of racket with hand's fingers on the upper side, the index finger and middle finger are on the bottom side, racket frame facing the top forward according to the handle. Then, the legs are in open stance, footprints parallel to the net, knees slightly bent, the weight is slightly forward so it can feel the heels of both the legs. On the strike movement, the body is rotated to the side according to the hand that holding the racket according to the direction of the ball came. The racket is swinging backward with a shoulder-length racket frame. The leg that is opposite with the hand holding the racket back, moved forward to the net pointing where the ball will be hit or directed.

In the process of developing proficiency in a stroke, it is necessary to learn the principles that are used to strike suitable to the correct type of stroke. The principles according to Handaya (1988: 64) are (1) prepare the position, and devote to the next style (2) spin on the spot with the left hand to pull the racket back (3) step towards the net (4) advanced action from bottom to top.

To get a good forehand drive stroke, besides needing a good technique, it must be supported also by elements of good physical condition as well. An activity is often the result of two or more physical elements or a combination of various physical elements (Harsono, 1988: 112).

The role of physical condition in the implementation and the result of a basic technique of sports are relatively dominant. This is based on the opinion by Moeloek (1984: 127) who said that the increase that is obtained from physical exercise can be seen, among others, in the form of motion ability, not quickly feel tired, increase skills and etc.

The most important things to be noticed and remember when hitting the ball are: (1) ready position while waiting for the ball, (2) concentration, especially in keeping eyes on the ball, when the ball is loose from the opponent's racket, (3) move the foot or move into a good and proper position to be able to hit the ball as best as possible, (4) back swing, with swinging the racket to the back at the beginning of the stroke, (5) forward swing, which swings the racket from back to front to find the ball, (6) a good grip on the ball with the ball (impact) and (7) follow-through swing that swings the racket forward after hitting the ball.

\section{1) Ready Position}

Ready position is a preparatory position ahead of the opponent at doing a hit. On this trough position, the body bowed slightly, feet shoulder width apart, knees bent, racket is in front of the body and eyes are always fixed on the ball as well as the movement of the racket of opponent. In this case, do this position at any time when the opponent is doing a hit. By the time, the opponent makes a hit, do a split step, then move to the direction in which the opponent directs a forcing shot. The speed of a player's movement towards the ball determines the player is in positioning or not. The faster a player can move or react to the opponent's shot, so it will be the better outcome to defeat the opponent.

The speed of a player's reaction in moving is depending on the foresight of the player sees the motion of racket or an opponent's body. The accuracy of player sights is good for his motion outcomes (see Yajuvendra Singh, Rajpoot, Ghai. G.D. \& Bagchi Amritashis. 2015: 5). To be able to have a great and solid forehand drive, each player needs to be spry and master in speed of coming ball from an opponent's racket. It is very closely related to positioning. Whereas, a directing speed of the ball to an opposing player is related to ready position. Ready position in tennis is very important, if a player wants a good and perfect shot. Ready positions in the forehand drive are as follows: (1) grasp the racket like someone shakes hands (forehand eastern); (2) the racket grip towards body and racket head toward net, its higher than racket grip; (3) standing with both feet in a relaxed position, (4) weight rests on both ends of the foot (weight forward), and (5) foresight focus. For more details techniques of ready position can be seen in the pictures below. 


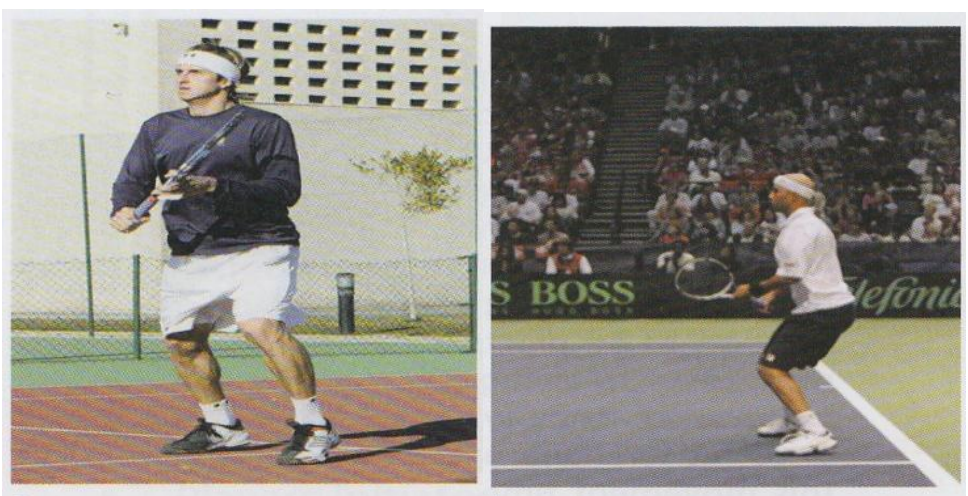

Photos source: Bruce, et al. (2009: 36)

Picture 1. Ready Position to Hold the Ball

\section{2) The way of moving}

After the split step, the first step is necessary to be noticed, either to move to the side (side step), to the back (back step), or forward (frontward step). There are three kinds of motion or step in tennis, which is a regular movement (sequential side step), free movement (free step) combined movement (combination step). One of the most fundamental thing in tennis, it must have held and believed by the tennis player that after having a drive technique well, then the next thing are the player's movement system or footwork. A better footwork of a tennis player, it is also better for the hit will be. After a combination movements split step a player, a player must have performed side step motion, then do the motion running towards the ball, this is done when a player gets the balls away from the position of player self. In order to success in a forehand drive, a player waits for the ball before the ball is hit by the opponent bouncing, or reacts to the ball at the same time with the ball drop. It's done to avoid a bigger fault. How to hit the ball (the way of stroking) should be done in a simple and efficient way, either by forehand or backhand.

Once the player is in a ready position to hit, then the next thing to note is the backswing movement. A good backswing movement is the length of the pull back should not exceed the position of 180 degrees from the ready position or 90 degrees from the open stand position. Long backswing movement can arouse great power but also cause delays in hitting the ball. A power of the forehand drive is obtained from the result of a simultaneous movement consisting of hand swing, shoulder spin, waist rotation and power transfer from the hind leg to the forefoot. The backswing movement is limited by the waist's movement or less than forward swing of hand, so it simultaneously with shoulder, waist and power transfer from the hind leg to the front leg while controlling the surface of the racket. Implementation movements are as follows: (1) move the weight and rest on the front leg, (2) swing the racket backswing together with the rotation of the body until the left shoulder accompanies the net and the position of the racket as high as between knee and shoulder, (3) the wrist should not be moved and the elbow should not be bent, (4) focus the sight toward the ball and glance at the target, (5) step into the target where the ball is droping and keep a glance at the target, and (6) swing the racket forward (foreward swing) and hit the ball as soon as possible towards the target (See Hillway, 2014: 485). For more details backswing movement can be seen in the pictures below: 

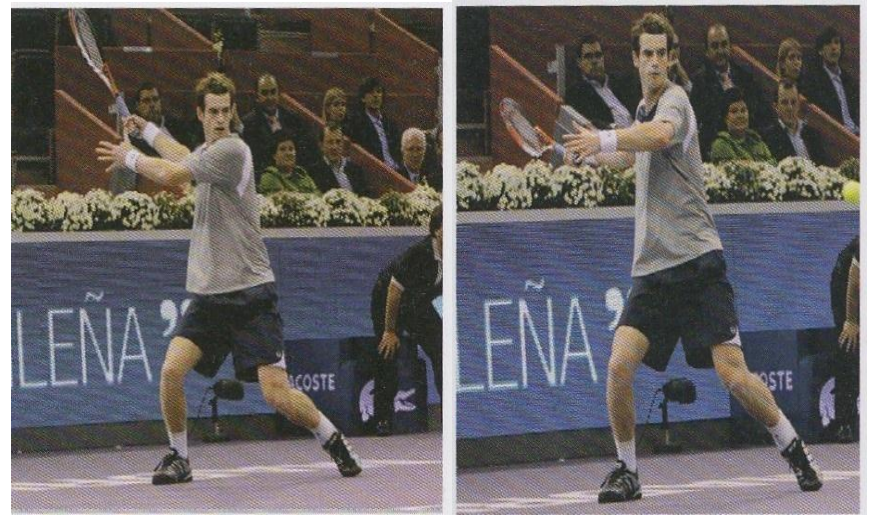

Photos source: (ibid, 65)

Picture 2. Backswing Movement

\section{3) Follow Through}

There are two versions of follow through, i.e. the player completes the straight movement with a note that the racket not lower than shoulder, and the player with the bent elbow position like elbowing someone's face who can gain additional power. The sequence of follow-through movements is as follows: (1) when the impact occurs, the hand and the racket do not play immediately, (2) focus on the direction of the ball to be hit preferably, (3) the racket and hand are swung forward along with the waist and shoulders rotation in a perfect motion, (4) the movement stops at one point and confronts the upper of left shoulder, (5) the weight moves to the forefoot, and (6) the elbow and sight position facing to the net (see, Seff, Fahmi, R. Widyonarto Marison \& Yasep Setyakarnawijaya, 2017: 37). For more details of follow through can be seen in the pictures below:
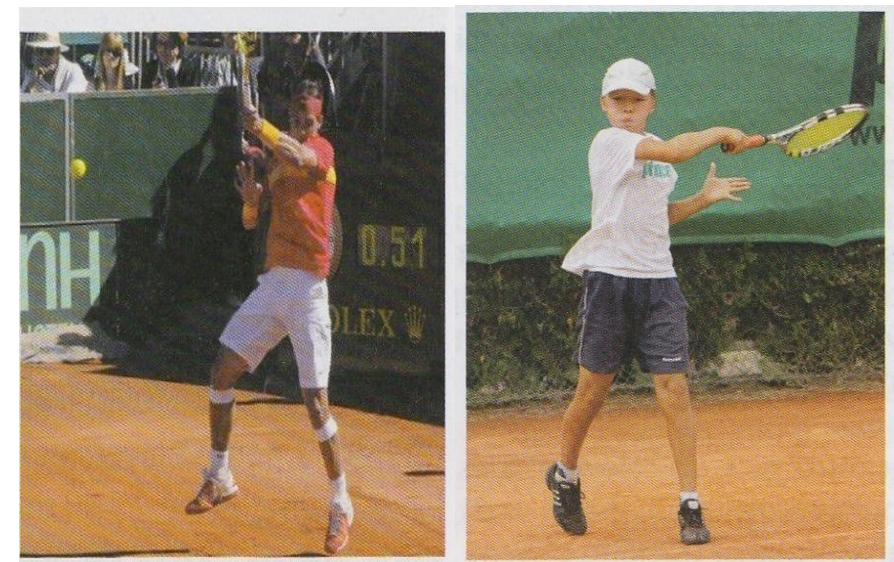

Photos Source: (ibid, 59)

Picture 3. Follow Through

As described by Brown (1996) and Strarbuck (2015) about greater attack or angle of attack, that at doing of a forehand drive, the movement of the limb is a motion series of the waist, knee bent, keep of the back straight and move toward the ball will be hit. The sequencing of forehand drive moves process is begun from how to hold the racket, ready position, backswing (turning, backswing, step, forwardswing and point of impact, follow through and result of stroke). 


\section{Conclusion}

For more details, the movement of the forehand drive stroke can be seen in the following figures:
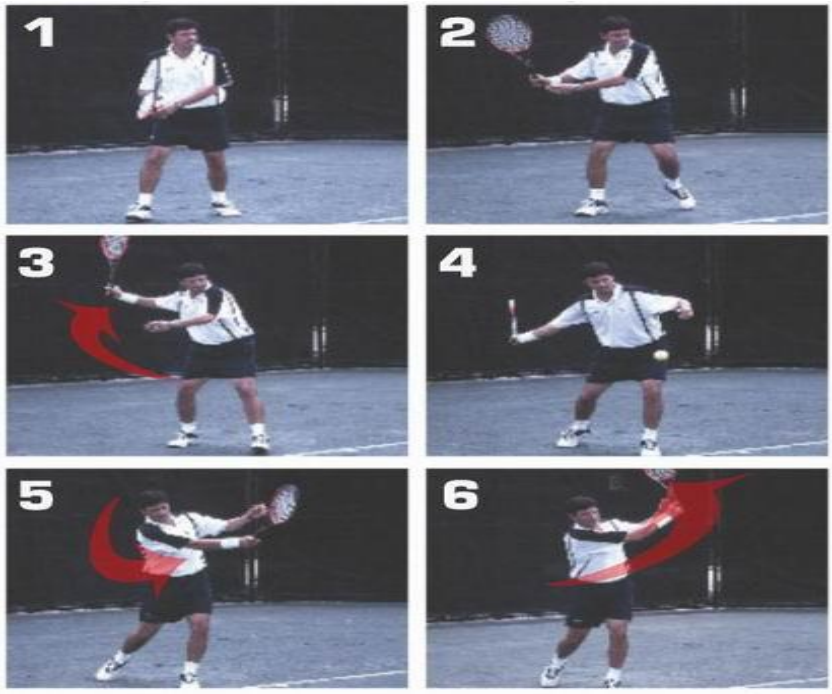

Photos Source: www.fuzzyyellowballs.com

Picture 4. Movements Series of Forehand Drive

Referring of description above, we are concluded that the interaction between strategy forehand drills and arm strength to the ability of forehand drive in tennis is influenced by arm strength, arm muscle ability to accept the load in various positions, and situation in a certain time without experience of fatigue.

\section{Conflict of interest statement and funding sources}

As author whose name is listed immediately, I certify that I have no affiliation with or involvement in any organization or with any financial interest in the subject matter or materials discussed in this manuscript, and this study represented by private financial funding of author.

\section{Statement of authorship}

I certify that the manuscript has original concept, design, and analyzed by author and I sufficiently in the work to take public responsibility for the content. Futhermore, I have approved the final article to published in International Journal of Physical Sciences and Engineering.

\section{Acknowledgments}

My greatest thank to Allah swt. for the all blessing to author so that the author can complete this manuscript. I would also like to show my gratitude to:

1) Prof. Dr. Muh. Zamrun F., S.Si., M.Si., M.Sc. as the Rector of Halu Oleo University

2) Dr. Jamiludin, S.Pd., M.Hum. as the Dean of Training and Education Faculty of Halu Oleo University

3) Lilik Rita Lindayani, S.Pd., M.Hum for all support as Researcher and

for the opportunity they gave so that this manuscript can be published. Finally, I realize that this manuscript is far from perfect. Therefore, constructive critique and suggestion are welcome to achieve the completeness of this manuscript. I expect this manuscript will be useful for the reader.

Sawali, L. (2018). Drills forehand training strategy on the stroke of forehand drive ability in tennis. International Journal Of Physical Sciences And Engineering (IJPSE), 2(2), 11-20. 


\section{References}

1. Brown, E. K., \& Miller, J. E. (Eds.). (1996). Concise encyclopedia of syntactic theories. Pergamon Press. View in (Google Scholar)

2. Elliott, B., Reid, M., \& Celda, M. C. (2009). Technique development in tennis stroke production. International Tennis Federation.

View in (Google Scholar)

3. Misbahuddin, M., Abdurrahman, A., \& Razali, R. (2018). Hubungan Power Otot Lengan dengan Kemampuan Servis Tenis Lapangan Mahasiswa Penjaskesrek FKIP Unsyiah Angkatan 2014. Jurnal Ilmiah Mahasiswa Pendidikan Jasmani, Kesehatan dan Rekreasi, 3(4).

View in (Google Scholar)

4. Elliott, B., Fleisig, G., Nicholls, R., \& Escamilia, R. (2003). Technique effects on upper limb loading in the tennis serve. Journal of Science and Medicine in Sport, 6(1), 76-87.

View in (Google Scholar)

5. Harsono, M. S., \& Drs, M. S. (1988). Coaching dan Aspek-aspek Psikologis dalam Coaching. View in (Google Scholar)

6. Kimball, W. F. (2017). The United States Tennis Association: Raising the Game. U of Nebraska Press. View in (Google Scholar)

7. Raiffa, H. (1961). Risk, ambiguity, and the Savage axioms: comment. The Quarterly Journal of Economics, 75(4), 690-694.

View in (Google Scholar)

8. Lardner, R. (1992). Teknik dasar tenis: strategi dan taktikyang akurat. Dahara Prize.

View in (Google Scholar)

9. Magethi, B. (1990). Tenis Para Bintang. Bandung: Pionir Jaya.

View in (Google Scholar)

10. Moeloek, D., \& Tjokronegoro, A. (1984). Kesehatan dan olahraga. Jakarta: Fakultas Kedokteran Unversitas Indonesia.

View in (Google Scholar)

11. Mottram, T. (1996). Fundamental tenis: resep meraih kemenangan. Effhae \& Dahara Prize. View in (Google Scholar)

12. Pate, R. R; Bruce McClenaghan; dan Robert Rotella,. 1993. Dasar-dasar Ilmiah Kepelatihan. View in (Google Scholar)

13.Seff, F., Marison, R. W., \& Setiakarnawijaya, Y. (2017). Tingkat keberhasilan groundstroke forehand dan backhand pemain tim nasional tenis lapangan indonesia pada pertandingan davis cup antara indonesia vs vietnam maret 2016 di solo. Jurnal Ilmiah Sport Coaching and Education, 1(1), 29-43.

View in (Google Scholar)

14. Siahaan, D. (2017). Pengaruh latihan horizontal swing dan latihan side lateral raise terhadap kemampuan forehand drive dalam permainan tenis lapangan. Jurnal prestasi, 1(2).

View in (Google Scholar) 
15.Starbuck, C., Damm, L., Clarke, J., Carré, M., Capel-Davis, J., Miller, S., ... \& Dixon, S. (2016). The influence of tennis court surfaces on player perceptions and biomechanical response. Journal of sports sciences, 34(17), $1627-1636$.

View in (Google Scholar)

16. Bootsma, R. J., \& van Wieringen, P. C. (1990). Timing an attacking forehand drive in table tennis. Journal of experimental psychology: Human perception and performance, 16(1), 21.

View in (Google Scholar)

17. Yudoprasetio, 1999. Olahraga Tenis (Second Edition). Jakarta: Bhratara Karya Aksara. View in (Google Scholar)

18. Wiardani, N. K., Kusumajaya, A. N., \& Arsana, I. W. J. (2018). Macronutrient Intake and Metabolic Syndrome Status towards Tour Guide. International Journal of Health Sciences (IJHS), 2(1), 29-43.

View in (Google Scholar)

19. Lindayani, L. R., Masri, F. A., Idul, R., \& Sawali, L. (2018). A metaphorical analysis of Kabhanti Modero to show Munanese social relations. International Journal of Linguistics, Literature and Culture (IJLLC), 4(2), 72-80.

View in (Google Scholar)

20. Kumar, P., \& Mishra, A. (2018). Residents perception analysis of tourism traits and its impact on prospects of Jharkhand tourism. International Journal of Business, Economics \& Management (IJBEM), 1(1), 1-22.

View in (Google Scholar)

Sawali, L. (2018). Drills forehand training strategy on the stroke of forehand drive ability in tennis. International Journal Of Physical Sciences And Engineering (IJPSE), 2(2), 11-20. doi:10.29332/ijpse.v2n2.133 


\section{Biography of Author}

\begin{tabular}{|l||}
\hline \\
Education Background: \\
S1 Physical and Healthy Education of Manado State University \\
S2 Environmental Heathly of Gadjah Mada University \\
S3 Physical Education of Jakarta State University \\
Previous Publication: \\
1) Community Participation for Garbage Processing in Kendari, Gerbang Inovasi \\
Journal Volume 7 No. 15-16 ISSN: 0854-8935, Januari 2012 \\
2) The Influence of Strength Endurance Exercise into Forehand Drive in Tennis \\
Court. Gema Pendidikan Journal Volume 24 No. 1 ISSN: 0854-9044, Januari 2017. \\
3) A Metaphorical Analysis of Kabhanti Modero to Show Munanese Social \\
Relations. International Journal of Linguistics, Literature and Culture Vol. 4 No. 2, \\
March 2018, pages: 72-80, ISSN: 2455-8028, https://doi.org/10.21744/ijllc.v4i2.660 \\
online at https://jicujournal.us/ \\
Email: sawali_la@yahoo.co.id \\
\hline
\end{tabular}

